\title{
ANALISIS INTRUSI AIR LAUT DENGAN PENGUKURAN TOTAL DISSOLVED SOLIDS (TDS) AIR SUMUR GALI DI KECAMATAN PADANG UTARA
}

\author{
Reri Afrianita, Tivany Edwin, Aroiya Alawiyah \\ Jurusan Teknik Lingkungan, Fakultas Teknik, Universitas Andalas \\ Email: rerianita@ft.unand.ac.id
}

\begin{abstract}
ABSTRAK
Penelitian ini bertujuan untuk menganalisis pengaruh intrusi air laut dengan pengukuran TDS pada air sumur gali di Kecamatan Padang Utara. Pengukuran TDS dilakukan di tiga kelurahan di Kecamatan Padang Utara yaitu Kelurahan Air Tawar Barat, Ulak Karang Selatan, dan Ulak Karang Utara dengan frekuensi pengambilan sampel sebanyak dua kali yaitu pada bulan November 2015 dan Februari 2016. Konsentrasi TDS pada November 2015 berada dalam rentang 20-9000,8 mg/L, sedangkan pengukuran konsentrasi TDS pada Februari 2016 berada dalam rentang 160,8-735,2 mg/L. Pengukuran TDS pada ovember 2015 menunjukkan bahwa terdapat tiga sumur yang yang terindikasi mengalami intrusi air laut, yaitu ULS 8 (1101,6 mg/L), ULS 9 $(9000,8 \mathrm{mg} / \mathrm{L})$, dan ULU $6(1926,4 \mathrm{mg} / \mathrm{L})$. Hubungan antara jarak sumur dari bibir pantai terhadap nilai TDS memiliki koefisien korelasi sebesar 0,118 - 0,095, hal ini menunjukkan tidak adanya pengaruh antara jarak dengan nilai TDS. Hasil penelitian menunjukkan bahwa terdapat beberapa sumur yang terindikasi mengalami intrusi air laut di sepanjang pesisir di Kecamatan Padang Utara.
\end{abstract}

Kata kunci: intrusi air laut, jarak, Kecamatan Padang Utara, sumur gali, TDS

\begin{abstract}
This research aims to analyze the effect of seawater intrusion with measurement of TDS dug well water in Padang Utara Subdistrict. The measurements of TDS carried out in three villages in Padang Utara Subdistrict, namely the Village are Air Tawar Barat, Ulak Karang Selatan, and Ulak Karang Utara with twice sampling frequency: on November 2015 and February 2016. TDS concentration in November 2015 is in the range of 20 to $9000.8 \mathrm{mg} / \mathrm{L}$, while the measurement of TDS concentration in February 2016 is in the range of 160.8 to $735.2 \mathrm{mg} / \mathrm{L}$. Measurement of TDS in November 2015 showed that there were three wells that indicated to seawater intrusion, i.e. the ULS 8 (1101.6 $\mathrm{mg} / \mathrm{L})$, ULS 9 (9000.8 $\mathrm{mg} / \mathrm{L})$, and ULU 6 (1926.4 $\mathrm{mg} / \mathrm{L})$.. Correlation between TDS concentration with coastline distance have a value $r$ amounted to 0,118-.095. The results showed that there are some wells that indicated to seawater intrusion along the coast in Padang Utara Subdistrict.
\end{abstract}

Keywords: distance, dug wells Padang Utara Subdistrict, , seawater intrusion, TDS 


\section{PENDAHULUAN}

Berdasarkan data PDAM Kota Padang (2015), terdapat sekitar 270.000 rumah tangga di Kota Padang dan hanya sekitar 85.000 rumah tangga yang dapat terlayani oleh PDAM Kota Padang melalui sistem air perpipaan. Kecamatan Padang Utara merupakan salah satu kecamatan di Kota Padang dengan jumlah penduduk sebanyak 70.050 jiwa (BPS, 2013). Tingkat pelayanan PDAM di Kecamatan Padang Utara hanya sebesar $45 \%$, sehingga masyarakat yang belum dilayani oleh PDAM menggunakan sumur untuk memenuhi kebutuhan air bersih mereka. Penggunaan air sumur di Kecamatan Padang Utara diperkirakan akan terus mengalami peningkatan seiring pertumbuhan penduduk.

Penduduk yang tinggal di sekitar pantai di Kecamatan Padang Utara memanfaatkan air sumur untuk memenuhi kebutuhan sehari-hari mulai dari memasak, mencuci, mandi dan kebutuhan lainnya. Berdasarkan survey yang telah dilakukan, Kecamatan Padang Utara merupakan wilayah pesisir dan terdapat pemukiman yang dekat dengan pantai dan terdapat keluhan dari masyarakat sekitar pantai yang menyatakan bahwa air yang keluar pada mata air di sumur-sumur masyarakat berwarna keruh atau kuning dan rasanya agak asin. Keluhan masyarakat tersebut merupakan indikasi awal terjadinya pencemaran air tanah di daerah pesisir pantai yang disebabkan oleh air laut. Pencemaran air tanah oleh air laut ini dinamakan intrusi air laut.

Intrusi air laut merupakan suatu peristiwa penyusupan atau meresapnya air laut atau air asin ke dalam air tanah. Kasus intrusi air laut merupakan masalah yang sering terjadi di daerah pesisir pantai. Masalah ini selalu terkait dengan kebutuhan air bersih, dimana air bersih merupakan air yang layak untuk dikonsumsi. Rusaknya air tanah pada daerah pesisir ditandai dengan keadaan air yang tidak bersih dan rasanya asin (Indahwati dkk, 2012).

Selama ini intrusi air laut belum terlalu diperhatikan oleh masyarakat maupun pemerintah. Padahal, walaupun dampaknya tidak dirasakan secara langsung seperti halnya pencemaran udara dan suara, untuk jangka panjang rembesan air laut ke daratan akan menimbulkan kerugian yang sangat besar, baik dari segi lingkungan, kesehatan, bahkan ekonomi. Intrusi air laut dapat menyebabkan dampak yang sangat luas dalam berbagai aspek kehidupan, seperti gangguan kesehatan, penurunan kesuburan tanah, kerusakan bangunan dan lain sebagainya (Widada, 2007).

Indikator terjadinya intrusi air laut dapat diketahui dengan melakukan pengukuran konsentrasi Total Dissolved Solids (TDS) untuk menentukan jumlah garam terlarut pada sumur penduduk. TDS merupakan parameter fisik air baku dan ukuran zat terlarut, baik zat organik maupun anorganik yang terdapat pada larutan. TDS mencakup jumlah material dalam air, material ini dapat berupa karbonat, bikarbonat, klorida, sulfat, fosfat, nitrat, kalsium, magnesium, natrium, ion-ion organik, dan ion-ion lainnya. Kandungan TDS dalam air juga dapat memberi rasa pada air yaitu air menjadi seperti garam, sehingga jika air yang mengandung TDS terminum, maka akan terjadi akumulasi garam di dalam ginjal manusia, sehingga lama-kelamaan akan mempengaruhi fungsi fisiologis ginjal (Krisna, 2011). Klasifikasi air berdasarkan jumlah garam terlarut dan dapat dilihat pada Tabel 1 berikut.

Tabel 1. Kriteria Penilaian TDS (Total Dissolved Solids)

\begin{tabular}{ccc}
\hline No & Nilai TDS $(\mathbf{m g} / \mathbf{L})$ & Tingkat Salinitas \\
\hline 1 & $0-1.000$ & Air tawar \\
\hline 2 & $1.001-3.000$ & Agak asin/payau (slightly saline) \\
\hline 3 & $3.001-10.000$ & Sedang/payau (moderately saline) \\
\hline 4 & $10.001-100.000$ & Asin (saline) \\
\hline 5 & $>100.000$ & Sangat asin (brine) \\
\hline
\end{tabular}

Sumber: Mc Neely et al, dalam Effendi (2003)

Berdasarkan latar belakang tersebut dan belum adanya penelitian yang dilakukan di daerah ini terutama yang berhubungan dengan studi pengaruh air laut terhadap air tanah di daerah pesisir Padang Utara, maka perlu dilakukan penelitian terkait studi intrusi air laut pada kawasan pesisir Padang Utara Kota Padang dengan melakukan pengukuran TDS dari beberapa sampel yang diambil dari sumursumur penduduk. 


\section{METODOLOGI PENELITIAN}

Lokasi Penelitian

Metode sampling dilakukan dengan menggunakan metode Purposive Sampling. Metode Purposive Sampling merupakan salah satu teknik pengambilan sampel dengan ketentuan tertentu sesuai kebutuhan penelitian. Penelitian ini memiliki ketentuan sumur yaitu sumur yang diambil merupakan sumur yang digunakan oleh masyarakat untuk sumber air bersih dan digunakan untuk keperluan domestik seperti mandi, menyikat gigi, mencuci pakaian, mencuci alat-alat makan, memasak dan sebagainya. Berdasarkan metode ini dipilihlah lokasi sumur di 3 kelurahan dari 7 kelurahan yang ada di kawasan Kecamatan Padang Utara Kota Padang sebagai lokasi penelitian. Pemilihan ini berdasarkan kelurahan-kelurahan yang berada di pinggir pantai. Ketiga lokasi sampling yang terpilih yakni Kelurahan Air Tawar Barat, Kelurahan Ulak Karang Utara dan Kelurahan Ulak Karang Selatan.

\section{Waktu Penelitian}

Penelitian dimulai pada bulan November 2015 dan tidak memperhitungkan kondisi musim atau cuaca pada daerah penelitian karena tujuan penelitian untuk melihat sebaran konsentrasi TDS secara umum di Kecamatan Padang Utara. Pengambilan sampel dilakukan selama tiga bulan karena mengacu pada SNI 06-2412-1991 tentang Pengambilan Contoh Kualitas Air dimana pengambilan air tanah dilakukan setiap tiga bulan sekali selama 1 tahun, namun karena keterbatasan dana dan waktu maka penelitian dilakukan dengan dua kali pengambilan sampel.

\section{Pengumpulan Data}

- Data Lapangan

Data lapangan ini meliputi pengisian lembar data lapangan untuk sampling air tanah yang terdapat pada lampiran SNI 6989.58:2008 serta wawancara dengan masyarakat yang sumurnya dijadikan sebagai lokasi sampling. Sebelum melakukan pengumpulan data primer, alat yang perlu disiapkan adalah: a. Global Position Satelite (GPS) untuk menentukan koordinat sumur;

b. Roll Meter, untuk mengukur dimensi sumur;

c. Alat tulis.

Data yang diperoleh yaitu:

a. Data kedalaman sumur;

b. Data tinggi muka air sumur;

c. Data lebar sumur;

d. Koordinat titik sampel;

e. Lokasi tempat survey;

f. Ketinggian topografi;

g. Data jarak antara sumur dengan tepi laut, yang diperoleh dengan aplikasi Mapsource..

- Data Laboratorium

a. Langkah-langkah dari pengambilan sampel pada penelitian ini adalah sebagai berikut: Pengambilan sampel dilakukan pada 30 sumur di kawasan pesisir Kecamatan Padang Utara pada pagi hari dengan jarak dari bibir pantai $\pm 200 \mathrm{~m}$ sebanyak $1 \mathrm{~L}$, lalu air yang diambil dimasukkan ke dalam botol dan dibawa ke laboratorium untuk diuji;

b. Pengambilan sampel dilakukan dengan menggunakan alat vertical water sampler dan dibenamkan sedalam 20 $\mathrm{cm}$ di bawah permukaan air apabila sumur penduduk terbuka, apabila sumur penduduk ditutup maka pengambilan sampel dilakukan menggunakan kran air dan dibiarkan air mengalir selama 1-2 menit sebelum sampel diambil;

c. Penyimpanan sampel dilakukan dengan alat pendingin pada suhu $4-2^{\circ} \mathrm{C}$ sebelum digunakan untuk pengukuran TDS.

- Peta Titik Sampling

Peta titik sampling yang diambil di Kecamatan Padang Utara dapat dilihat pada Gambar 1. 


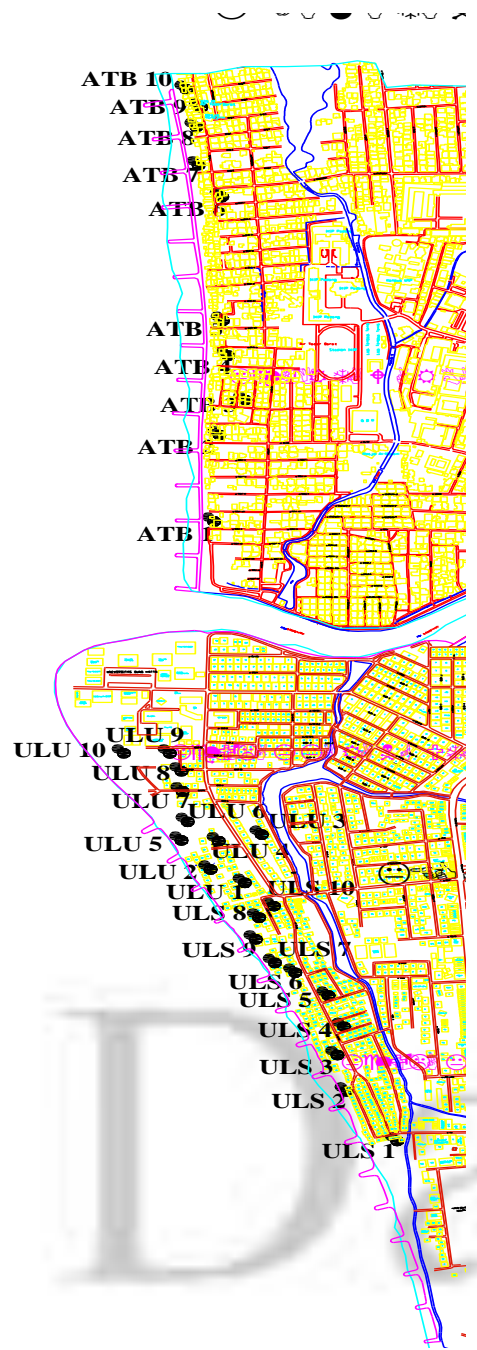

Gambar 1. Peta Lokasi Sampling
1. Perhitungan TDS

Hasil penimbangan dihitung dengan menggunakan persamaan berikut (Greenberg dkk, 1992):

TDS $=(B-A) \times 1000 / 25 \mathrm{~mL}$ sampel $\times 1000$

Keterangan:

$\mathrm{B}=$ Berat cawan berisi residu terlarut

$\mathrm{A}=$ Berat cawan kosong

2. Analisis Data

3. Analisis data dan pembahasan meliputi perhitungan konsentrasi TDS dan menggunakan analisis regresi. Analisis regresi dilakukan untuk melihat hubungan antara konsentrasi TDS terhadap jarak pengambilan sampel dari bibir pantai. Analisis regresi yang dilakukan meliputi analisis regresi linier dan non linier. Analisis regresi non linier dilakukan dengan menggunakan tipe polinomial, eksponen dan logaritma

\section{HASIL DAN PEMBAHASAN}

\section{Pengukuran Konsentrasi TDS}

Data koordinat pengambilan sampel dan hasil perhitungan TDS pada air sumur penduduk di Kecamatan Padang Utara dapat dilihat pada Tabel 2

Tabel 2 Data Koordinat dan Konsentrasi TDS

\begin{tabular}{|c|c|c|c|c|c|}
\hline $\begin{array}{c}\text { No } \\
\text { • }\end{array}$ & $\begin{array}{c}\text { Kode } \\
\text { Sampel }\end{array}$ & $\begin{array}{c}\text { Bujur Timur } \\
\qquad\left({ }^{\circ}\right)\end{array}$ & $\begin{array}{c}\text { Lintang Selatan } \\
\left(^{\circ}\right)\end{array}$ & $\begin{array}{c}\text { TDS }(\mathrm{mg} / \mathrm{L}) \text { Pada November } \\
2015\end{array}$ & $\begin{array}{c}\text { TDS } \\
\text { (mg/L) } \\
\text { Pada } \\
\text { Februar } \\
\text { i } 2016\end{array}$ \\
\hline 1 & ATB 1 & 100,2040 & 0,5406 & 76 & 202.4 \\
\hline 2 & ATB 2 & 100,2040 & 0,5400 & 292.8 & 387.2 \\
\hline 3 & ATB 3 & 100,2043 & 0,5357 & 291.2 & 340 \\
\hline 4 & ATB 4 & 100,2040 & 0,5351 & 452 & 280 \\
\hline 5 & ATB 5 & 100,2041 & 0,5348 & 263.2 & 244.8 \\
\hline 6 & ATB 6 & 100,2041 & 0,5338 & 479.2 & 456 \\
\hline
\end{tabular}






Sumber: Data Penelitian, 2016

Keterangan: $\quad$ ATB (Air Tawar Barat);

ULS (Ulak Karang Selatan);

ULU (Ulak Karang Utara).

Berdasarkan Tabel 2 dapat terlihat bahwa ratarata konsentrasi TDS berada pada kategori air tawar. Namun, pada ULS 8, ULS 9, dan ULU 6 air sumur telah terindikasi mengalami intrusi air laut. Berdasarkan kriteria penilaian TDS pada Tabel 2, pengukuran konsentrasi TDS pada bulan November 2015 memberikan hasil bahwa air sumur pada ULS 8 dan ULU 6 termasuk dalam kategori agak asin/payau dengan konsentrasi TDS berada diantara 1.001-3.000 mg/L, sedangkan konsentrasi TDS pada ULS 9 masuk ke dalam kategori sedang/payau karena berada pada rentang $3.001-10.000 \mathrm{mg} / \mathrm{L}$. 
Pengukuran konsentrasi TDS pada bulan Februari 2016 memberikan hasil yang berbeda, dimana tidak satupun sumur masyarakat yang terindikasi mengalami intrusi air laut. Hal ini dapat dilihat pada Tabel 1. Data konsentrasi TDS pada bulan Februari 2016 masih dikategorikan sebagai air tawar karena semua sumur berada pada rentang 0$1000 \mathrm{mg} / \mathrm{L}$.

Berdasarkan Tabel 2 juga dapat diketahui bahwa terjadi perubahan antara konsentrasi TDS pada bulan November 2015 dan bulan Februari 2016. Secara umum, konsentrasi TDS pada bulan Februari 2016 menurun atau jauh lebih rendah daripada konsentrasi TDS pada bulan November 2015. Konsentrasi rata-rata TDS pada bulan November 2015 sebesar $741,2 \mathrm{mg} / \mathrm{L}$ dan konsentrasi rata-rata TDS pada bulan Februari 2016 sebesar 385,09 $\mathrm{mg} / \mathrm{L}$.

Damayanti (2015), menyatakan bahwa pada saat terjadi pasang, air laut akan merembes masuk ke dalam air tawar. Hal tersebut terjadi karena adanya hubungan hidrolik antara air asin dan air tawar. Air asin memiliki kadar mineral lebih tinggi dan tekanan air yang lebih besar dibandingkan air tawar, sehingga air laut memiliki massa jenis yang lebih tinggi dan tekanan air yang lebih besar. Air kemudian akan masuk melalui celah air laut untuk bergerak ke daratan, sehingga menyebabkan sumur-sumur dangkal banyak yang terkontaminasi. Penelitian yang berkaitan dengan kondisi pasang surut air laut adalah penelitian oleh Lestari dkk (2011), dengan judul pengaruh kenaikan permukaan air laut pada intrusi air laut di akuifer pantai (Studi Kasus: Pulau Bintan Provinsi Kepulauan Riau) dan memberikan hasil bahwa fluktuasi atau naik turunnya interface air laut-air tawar dan naik turunnya muka air laut tidak mempengaruhi kualitas air sumur. Hal ini menunjukkan bahwa pasang surut air laut tidak berpengaruh terhadap konsentrasi TDS pada air sumur di Kecamatan Padang Utara.

Perbedaan konsentrasi TDS pada bulan November 2015 dan bulan Februari 2016 dapat disebabkan oleh kondisi saat pengambilan sampel. Pengambilan sampel pada bulan November 2015 dilakukan saat kondisi setelah hujan, sehingga konsentrasi TDS yang terukur menjadi lebih besar. Saat kondisi setelah hujan, air tanah yang mengalir lewat celah dan retakan mampu melarutkan mineral karena waktu kontak air tanah terhadap batuan yang dilaluinya relatif singkat. Berbeda dengan pengambilan sampel pada bulan Februari 2016 yang dilakukan saat kondisi panas sehingga waktu kontak air tanah terhadap batuan yang dilaluinya relatif lama dan menyebabkan air tanah menjadi jenuh terhadap mineral (Hariadi dan Tjahyo, 2008).

Berdasarkan data survey yang telah dilakukan, sumur pada ULS 8 digunakan sebagai sumber air bersih mulai dari minum, memasak, mencuci dan lain-lain sedangkan sumur pada ULS 9 dan ULU 6 tidak digunakan untuk minum tetapi digunakan untuk kebutuhan lain seperti mandi dan mencuci. Air sumur yang termasuk dalam kategori sedang/payau dan agak asin/payau tidak dapat digunakan sebagai air minum tapi dapat digunakan untuk kebutuhan lain.

Kodoatie (1996), menyatakan bahwa kadar garam di dalam air apabila melebihi batas kategori air tawar akan berdampak pada kesehatan manusia. Menurut Gustian dan Suharto (2005), masalah kandungan beberapa jenis garam terlarut yang tidak dikehendaki dapat menurunkan mutu bahan baku air minum. Adanya beberapa jenis garam dalam air dapat berasal dari mineral tanah atau batuan yang terlarut dalam air atau peresapan (intrusi) air laut ke daratan. Sumber air tanah pada kawasan pesisir mempunyai tingkat salinitas tinggi sehingga air tersebut tidak memenuhi syarat sebagai air minum.

\section{Hubungan Konsentrasi TDS Dengan Jarak Sumur Gali Dari Bibir Pantai}

Tingkat pencemaran air tanah dapat diketahui dengan analisis kualitasnya berdasarkan parameter TDS. Konsentrasinya tergantung pada kandungan garam-garam terlarut yang dapat terionisasi dalam air saat pengukuran dilakukan. Secara teoritis air laut memiliki konsentrasi TDS yang tinggi karena mengandung banyak senyawa kimia yang mengakibatkan tingginya nilai salinitas. Oleh 
karena itu, untuk memprediksi suatu daerah terintrusi air laut dapat dilihat pada pola penyebaran hubungan konsentrasi TDS terhadap jarak dari bibir pantai. Semakin jauh dari bibir pantai secara teoritis konsentrasi TDS akan semakin kecil (Saila dkk, 2013).

Indahwati dkk (2012), menyatakan bahwa kandungan garam-garam terlarut dalam air secara umum dapat berasal dari tengah laut dan konsentrasinya menipis menuju batasbatas daratan, yakni garis pantai. Pernyataan tersebut perlu dibuktikan kebenarannya melalui pengukuran salinitas melalui TDS dan jaraknya dari garis pantai.

Penentuan hubungan konsentrasi TDS dengan jarak sumur gali dari bibir pantai dilakukan dengan menggunakan analisis regresi. Analisis regresi yang dilakukan meliputi analisis regresi linier dan non linier, sehingga dapat dibandingkan koefisien korelasi (r) pada masing-masing analisis regresi yang dilakukan. Regresi polinomial memberikan nilai $r$ tertinggi pada pengukuran bulan November 2015 dan pengukuran pada bulan Februari 2016, dengan demikian analisis regresi yang digunakan adalah analisis regresi polinomial. Model polinomial menjelaskan bahwa konsentrasi TDS akan semakin tinggi seiring dengan jauhnya jarak sumur dari bibir pantai, namun apabila jarak sumur dari bibir pantai telah mencapai titik maksimalnya maka konsentrasi TDSnya akan turun. Hubungan konsentrasi TDS dengan jarak sumur dari bibir pantai lebih jelasnya dapat dilihat pada Gambar 2.

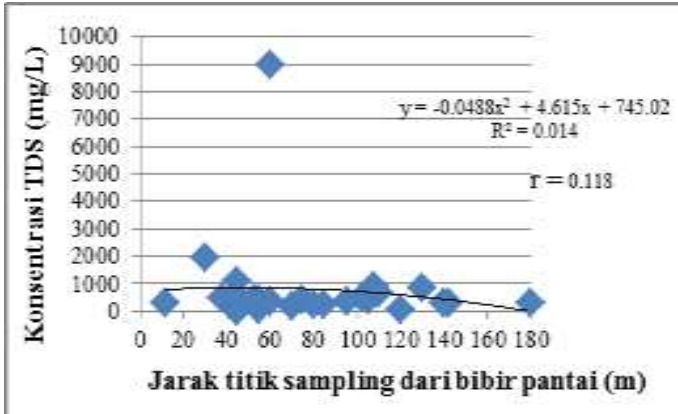

(a)

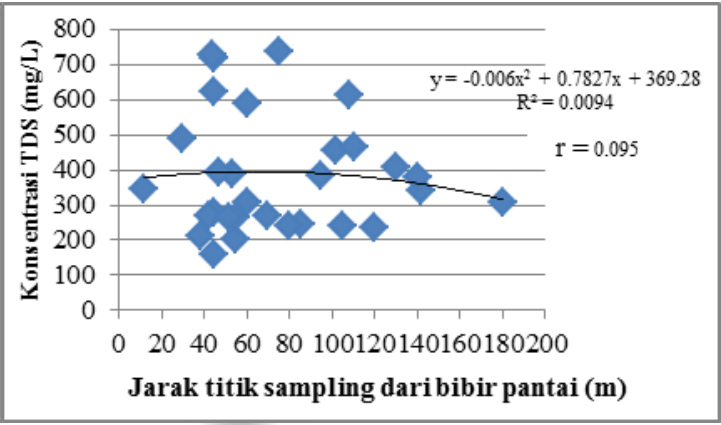

(b)

\section{Gambar 2. Perbandingan Konsentrasi TDS dengan jarak titik sampling dari bibir pantai} di Kecamatan Padang Utara

\section{(a) November 2015; (b) Februari 2016}

Berdasarkan Gambar 2 dapat diketahui bahwa koefisien determinasi $\left(\mathrm{R}^{2}\right)$ antara jarak titik sampling dengan konsentrasi TDS sangat jauh dari nilai satu yaitu pada bulan November 2015 sebesar 0.014 dan pada bulan Februari 2016 sebesar 0.009. Hal ini menunjukkan bahwa pada bulan November 2015 hanya $14 \%$ variabel dependen yaitu TDS dapat dijelaskan oleh faktor jarak terdekat ke bibir pantai sedangkan $86 \%$ dijelaskan oleh faktor ataupun variabel lainnya (variabel independen lainnya diluar model). Koefisien determinasi $\left(\mathrm{R}^{2}\right)$ pada bulan Februari 2016 mengalami penurunan, sehingga hanya 9\% jarak mempengaruhi konsentrasi TDS sedangkan $91 \%$ lainnya dijelaskan oleh faktor lain. Nilai $r$ pada penelitian ini berkisar antara 0,0-0,2 yang berarti mempunyai hubungan tak berkorelasi.

Menurut Sofiana, M (2007), dalam penelitiannya yang berjudul pengaruh jarak sumur dari pantai terhadap salinitas air sumur penduduk di wilayah pesisir Kecamatan Gayam Pulau Sapudi Kabupaten Sumenep memberikan hasil bahwa kadar air garam sumur pada tiap-tiap titik sampel terjadi tidak merata di Kecamatan Gayam dan dibagi menjadi dua zona air tanah, yaitu zona air tanah tawar dan zona air tanah payau. Penelitian di Kecamatan Gayam menunjukkan bahwa arah aliran air tanah di wilayah tersebut yaitu menyebar menuju pantai. Nilai korelasi 
yang didapatkan sebesar 36\% variasi salinitas dipengaruhi oleh variabel jarak, sedangkan sisanya dipengaruhi oleh faktor-faktor lain (kondisi fisik).

Suatu daerah yang terintrusi air laut dapat diprediksi dengan menghubungkan konsentrasi TDS terhadap jarak dari garis pantai (Husni dan Roh, 2012). Namun, hal tersebut tidak berlaku di Kecamatan Padang Utara. Faktor jarak dari garis pantai memiliki hubungan yang tak berkorelasi terhadap terjadinya intrusi air laut di daerah penelitian karena ada beberapa sumur yang jaraknya jauh dari garis pantai tetapi terkena dampak intrusi air laut dan ada beberapa sumur yang dekat dari garis pantai tetapi tidak terkena dampak intrusi air laut. Konsentrasi TDS di daerah penelitian memiliki sebaran yang bervariasi terhadap jarak. Perbedaan konsentrasi tersebut dapat disebabkan oleh jenis formasi batuan yang ada. Batuan formasi yang sama belum tentu memiliki tahanan jenis yang sama, sehingga didapatkan konsentrasi TDS yang bervariasi dari jarak garis pantainya. Beberapa faktor lain yang mempengaruhi konsentrasi TDS antara lain komposisi litologi dan kondisi batuan, komposisi mineral yang dikandung, kandungan benda cair, dan faktor eksternal lainnya (Nurrohim dkk, 2012).

\section{Pemetaan Sebaran TDS}

Peta kontur sebaran TDS pada daerah penelitian dapat dilihat pada Gambar 3 dan Gambar 4.

Gambar 3 dan Gambar 4 merupakan peta kontur sebaran TDS di Kecamatan Padang Utara yang diperoleh dengan menggunakan software Surfer 11. Berdasarkan gambar tersebut, di sebelah kiri adalah laut dan sebelah kanan merupakan daratan yang merupakan daerah penelitian. Garis kontur pada peta menggambarkan distribusi keruangan sebaran konsentrasi TDS di daerah penelitian. Nilai garis kontur tidak berubah dari tinggi ke rendah sejajar garis pantai pada sebelah kiri daerah penelitian, dengan demikian hal ini merupakan konfirmasi atas hasil regresi yang memiliki hubungan tak berkorelasi pada Gambar 2.

Gambar 3 dan Gambar 4 juga menjelaskan bahwa secara konsisten konsentrasi TDS yang tinggi terjadi pada ULS 9, sehingga diduga kemungkinan konsentrasi TDS yang tinggi ini disebabkan air laut yang terperangkap saat pembentukan daerah tersebut atau batuan daerah tersebut mengandung garam (Nasjono, 2010). Berdasarkan peta geologi Sumatera Barat, alluvium merupakan batuan penyusun yang tersusun atas lanau, pasir, dan kerikil yang umumnya terdapat di daerah pantai dan ada beberapa sisa batu apung tuf. Batuan penyusun di Kecamatan Padang Utara memiliki permeabilitas yang berbeda-beda sehingga dapat mempengaruhi kemampuan penyerapan air oleh tanah. Nasjono (2010), menyatakan bahwa variasi sebaran permeabilitas berdampak pada variasi salinitas air tanah.

Hasibuan dkk (2013), menyatakan bahwa porositas dan permeabilitas batuan sangat berpengaruh terhadap terjadinya intrusi air laut. Intrusi air laut akan terjadi jika air laut meresap memasuki air bawah tanah, hal ini bergantung pada nilai permeabilitas dan porositasnya. Semakin kecil nilai permeabilitas suatu batuan maka semakin susah untuk dilewati air resapan dari laut, karena rongga-rongga pada batuan tersebut akan semakin kecil. Sebaliknya, apabila porositas batuan semakin besar kemungkinan air lolos semakin sukar. Hal ini dilihat dari kemampuan dari batuan tersebut manahan air. Jika porositasnya kecil air resapan laut akan mudah melewatinya. Hal ini menunjukkan bahwa perbedaan konsentrasi TDS pada bulan November 2015 dan bulan Februari 2016 dapat disebabkan oleh kondisi permeabilitas masing-masing batuan penyusun di Kecamatan Padang Utara. 




Gambar 3. Peta Kontur Sebaran TDS pada November 2015

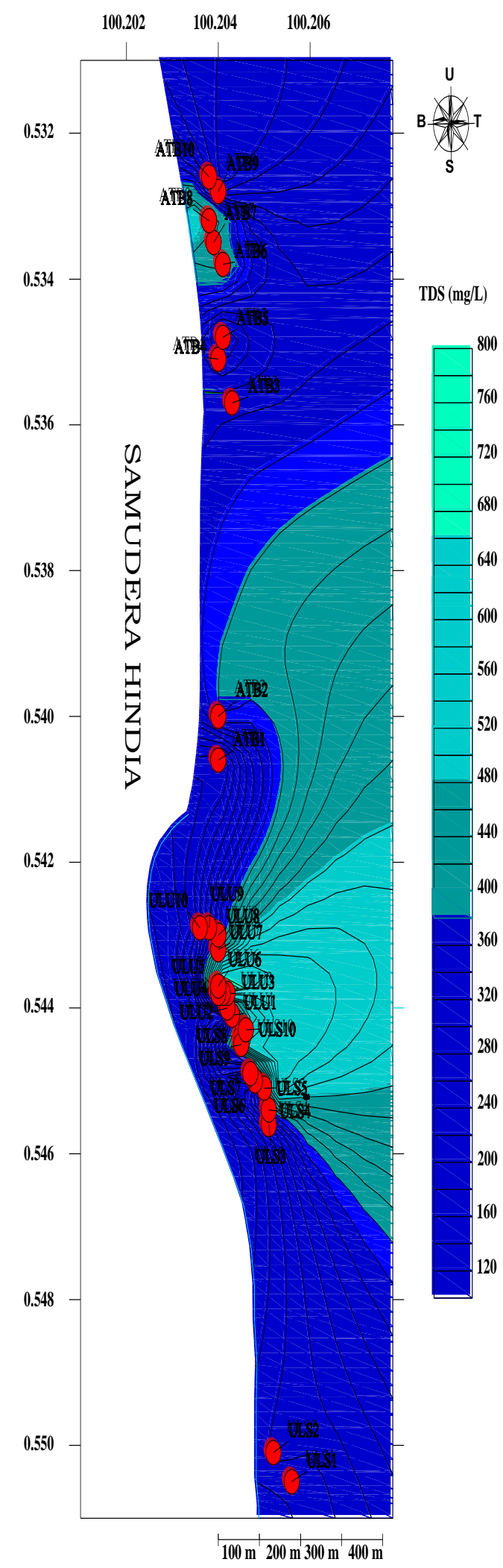

Gambar 4 Peta Kontur Sebaran TDS pada Bulan Februari 2016 


\section{SIMPULAN}

Konsentrasi TDS pada bulan November 2015 berada dalam rentang 20-9000,8 $\mathrm{mg} / \mathrm{L}$ dan masuk dalam rentang kategori air tawar hingga sedang/payau, sedangkan pengukuran konsentrasi TDS pada bulan Februari 2016 berada dalam rentang 160,8-735,2 $\mathrm{mg} / \mathrm{L}$ dan masuk dalam kategori air tawar;

Rata-rata konsentrasi TDS pada bulan November 2015 adalah sebesar 741,2 mg/L sedangkan rata-rata konsentrasi TDS pada bulan Februari 2016 adalah sebesar 385,09 $\mathrm{mg} / \mathrm{L}$ dan masih berada dalam kategori air tawar;

Konsentrasi TDS terhadap jarak sumur dari bibir pantai memiliki hubungan yang tak berkorelasi dengan nilai $r$ sebesar 0,118 pada bulan November 2015 dan 0,095 pada bulan Februari 2016;

Jarak sumur dari bibir pantai pada bulan November 2015 memberikan pengaruh sebesar 14\% terhadap konsentrasi TDS, sedangkan pada bulan Februari 2016 jarak sumur dari bibir pantai memberikan pengaruh sebesar 9\% terhadap konsentrasi TDS;

Peta kontur sebaran TDS menunjukkan bahwa pada bulan November 2015 terdapat sumur yang terindikasi mengalami intrusi air laut yaitu ULS 8 (1101,6 mg/L), ULS 9 (9000,8 $\mathrm{mg} / \mathrm{L})$, dan ULU 6 (1926,4 mg/L), sedangkan pengukuran pada bulan Februari 2016 tidak satupun sumur terindikasi mengalami intrusi air laut.

\section{DAFTAR PUSTAKA}

2412-1991. Metode Pengambilan Contoh Kualitas Air.

Badan Standarisasi Nasional. 2008. SNI.6989.58-2008. Metode Pengambilan Contoh Air Tanah.

BPS Padang. 2013. Padang Utara Dalam Angka Tahun 2013. Padang: Badan Pusat Statistik Kecamatan Padang Utara.

Damayanti, A., Rahman, D., Ardy, A. 2015. Studi Salinitas Air Tanah Dangkal Di Daerah Pesisir Bagian Utara Kota
Makassar. Jurnal Skripsi Unhas: Makassar.

Effendi, H. 2003. Telaah Kualitas Air bagi Pengelolaan Sumber Daya dan Lingkungan Perairan. Cetakan Kelima. Yogyakarta: Kanisius.

Greenberg, Arnold E., Lenore S, Andrew D. 1992. Standard Methods for the Examination of Water and Wastewater APHA/ AWWA/WEF. American Public Health Association: Washington DC 2005.

Gustian dan Suharto. 2005. Studi Penurunan Salinitas Air Dengan Menggunakan Zeolit Alam Yang Berasal Dari Bengkulu. Jurnal Gradien Vol.1 No.1: 38-42.

Hariadi dan Tjahyo. 2008. Variasi Temporal Hidrogeokimia Tetesan Dari Ornamen Drapery di Dalam Gua Gilap di Kawasan Karst Gunung Sewu, Kabupaten Gunung Kidul, DIY. Jurnal Kelompok Studi Fakultas Geografi UGM: Yogyakarta.

Hasibuan, F., Susilawati, Rahmatsyah. 2013. Studi Intrusi Air Laut Dengan Menggunakan Metode Resistivitas Listrik Konfigurasi Wenner-Schlumber Di Kecamatan Pantai Cermin Provinsi Sumatera Utara. Departemen Fisika Jl. Bioteknologi No.1 FMIPA USU Medan.

Husni, A dan Roh, S. 2012. Sebaran TDS, DHL, Penurunan Muka Air Tanah dan Prediksi Intrusi Air laut di Kota Tangerang Selatan. Jurnal Teknik Sipil dan Lingkungan. Fateta IPB.

Indahwati, N., Muryani C, Pipit, W. 2012. Studi Salinitas Airtanah Dangkal Di Kecamatan Ulujami Kabupaten Pematang Tahun 2012. Jurnal UNS: Surakarta.

Kodoatie, R. 1996. Pengantar Hidrogeologi. Yogyakarta: Penerbit ANDI.

Krisna dan Dwi, K. 2011. Faktor Risiko Kejadian Suspect Penyakit Batu Ginjal Di Wilayah Kerja Puskesmas Margasari Kabupaten Tegal Tahun 2010. Skripsi: Fakultas Ilmu Keolahragaan. Unnes.

Lestari, A., Kriyo, S., Suntoyo. 2011. Pengaruh Kenaikan Permukaan Air Laut pada Intrusi Air Laut di Akuifer Pantai (Studi Kasus : Pulau Bintan Provinsi Kepulauan Riau). Jurnal Teknik Kelautan ITS Surabaya. 
McNeely, R., et al. 1979. "Water Quality Source Book, A guide to Water Quality Parameter. Inland Waters Directorate Water Quality Branch, Ottawa, Canada”, dalam Effendi (2003).

Nasjono, J. 2010. Pola Penyebaran Salinitas Pada Akuifer Pantai Pasir Panjang, Kota Kupang, NTT. Jurnal Bumi Lestari. Volume 10 No.2.

Nurrohim, A., Tjaturahono, B., Wahyu, S. 2012. Kajian Intrusi Air Laut di Kawasan Pesisir Kecamatan Rembangan Kabupaten Rembang. Jurnal Unnes. Vol.1, No.1.

PDAM. 2015. Perusahaan Daerah Air Minum. Kota Padang.


Saila, M., Muhajjir, A. 2013. Pengaruh Intrusi Air Laut Terhadap Akuifer Pantai Pada Kawasan Wisata Pantai Iboh Sabang (187A). Jurnal Universitas Syiah Kuala. Konferensi Nasional Teknik Sipil (KoNTekS 7).

Sofiana, M. 2007. Pengaruh Jarak Sumur dari Pantai Terhadap Salinitas Air Sumur Penduduk di Wilayah Pesisir Kecamatan Gayam Pulau Sapudi Kabupaten Sumenep. Skripsi, Jurusan Pendidikan Geografi FMIPA Universitas Negeri Malang.

Widada, S. 2007. Gejala Intrusi Air Laut di Daerah Pantai Kota Pekalongan, Jurnal Ilmu Kelautan UNDIP. Vol 12(1):45-52.

Yamin, S dan Kurniawan, H. 2009. SPSS Complete: Teknik Analisis Statistik Terlengkap dengan Software SPSS, Buku Seri Pertama. Salemba Infotek: Jakarta.

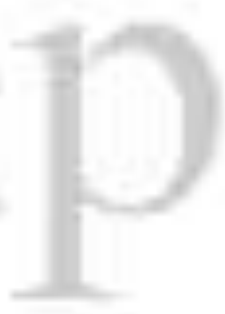

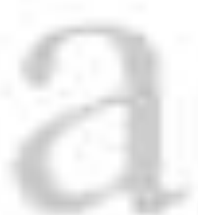

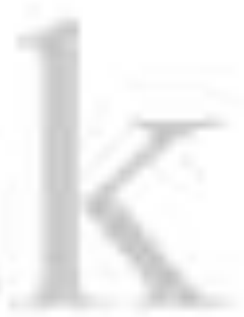

